\title{
NARRAR A RESTAURAÇÃO PORTUGUESA
}

\author{
NARRAR LA RESTAURAÇÃO PORTUGUESA
}

RACONTER LA RESTAURAÇÃO PORTUGAISE

NARRATING PORTUGUESE RESTAURAÇÃO

DOI: $\underline{10.5533 / 1984-2503-20113207}$

\section{Enrique Rodrigues-Moura}

\section{RESUMO}

A Restauração portuguesa (1640) teve lugar em uma época histórica caracterizada por uma alta "confessionalização" política e no auge de uma razão de estado que propugnava ativamente uma rígida "disciplina social". Este artigo propõe um modelo narrativo que descreve e explica o valor semântico das múltiplas narrativas legitimadoras da rebelião política que levou D. João IV ao poder: 1) Portugal florescente, anterior à Casa de Áustria; 2) união com Castela como cesura radical com um passado idealizado; 3) tempo de cativeiro, expiação e confiança na Providência; 4) libertação triunfante e pacífica; e 5) promessa jubilosa de um tempo de felicidade futura. De acordo com essa estrutura discursiva, as narrativas da Restauração baseiam-se em duas linhas conceptuais: legitimação de origem e legitimação no exercício do poder; tanto contra os Áustrias como a favor dos Bragança. Por último, defende-se que, da mesma forma que os Habsburgo cultivavam a pietas austriaca, os Bragança se apropriaram de uma pietas mariana já existente, com a intenção de justificar e consolidar a sua legitimidade política.

Palavras-chave: Restauração, narração, narratology, razão de estado, pietas mariana

\section{RESUMEN}

La Restauração portuguesa (1640) tuvo lugar en una época histórica caracterizada por una alta "confesionalización" política y en el auge de una razón de estado que 
propugnaba activamente una rígida "disciplina social". Este artículo propone un modelo narrativo que describe y explica el valor semántico de las múltiples narraciones legitimadoras de la rebelión política que llevó al poder a D. João IV: 1) Portugal floreciente, anterior a la Casa de Austria; 2) unión con Castilla como cesura radical con un pasado idealizado; 3) tiempo de cautiverio, expiación y confianza en la Providencia; 4) liberación triunfal y pacífica; y 5) promesa jubilosa de un tiempo de felicidad futura. De acuerdo con esta estructura discursiva, las narraciones de la Restauração se basan en dos líneas conceptuales: legitimidad de origen y legitimidad en el ejercicio del poder; tanto contra los Austrias como a favor de los Bragança. Por último, se defiende que, de la misma forma que los Habsburgo cultivaron una pietas austriaca, los Bragança se apropiaron de una pietas mariana ya existente, con la intención de justificar y consolidar su legitimidad política.

Palabras-clave: Restauração, narración, narratology, razón de estado, pietas mariana

\section{ABSTRACT}

The Portuguese Restauração (1640) took place during a period which was characterized by a high frequency of political "confessionalisation", and at its highpoint by "raison d'État" which actively defended a strict "social disciplining". This article puts forward a narrative structural pattern which describes and explains the semantic value of the multiple narrations that legitimize the political rebellion which led to the governance of D. João IV: 1) the flourishing Portugal, prior to the reign of the Habsburgs; 2) the unification with Spain as a radical break with an idealized past; 3 ) the period of captivity, expiation and trust in providence; 4) the triumphant and peaceful liberation; and 5) the joyous promise of future felicity. In accordance with this discursive structure, the Restauração narrations are based on two conceptual lines: the legitimacy of origin and the legitimacy of the execution of power, both against the Habsburgs and in favor of the Bragança. Last but not least, the text defends that the Bragança adapted the practices of the pietas mariana, which already existed, with the intention to justify and consolidate their political legitimacy just as the Habsburgs had done with the pietas austriaca.

Key words: Restauração, narration, narratology, raison d'État, pietas mariana

\section{RÉSUMÉ}

La Restauração portugaise (1640) eut lieu lors d'une époque historique caractérisée par une grande « confessionnalisation » politique et par l'apogée d'une raison d’État qui 
soutenait activement une rigide «discipline sociale». Cet article propose un modèle narratif qui décrit et qui explique la valeur sémantique de multiples narrations légitimant la rébellion politique qui fit accéder D. João IV au pouvoir: 1) le Portugal en essor, avant les Habsbourg; 2) L'union avec la Castille comme césure radicale pourvue d'un passé idéalisé; 3) temps de captivité, expiation et confiance en la Providence; 4) libération triomphale et pacifique; et 5) promesse jubilatoire d'un temps de future félicité. En accord avec cette structure discursive, les narrations de la Restauração se basent sur deux lignes conceptuelles: légitimité d'origine et légitimité quant à l'exercice du pouvoir, aussi bien contre les Habsbourg qu'en faveur des Bragança. Enfin, nous défendons, de la même manière que les Habsbourg exercèrent le culte de la pietas austriaca, les Bragança s'approprièrent d'une pietas mariana déjà existante, ayant l'intention de justifier et de consolider leur légitimité politique.

Mots-clés : Restauração, narration, narratology, raison d’État, pietas mariana

A estreita relação entre o poder político e a religião pode ser considerada uma constante histórica. Desde tempos remotos e até o advento do lluminismo europeu, o titular do poder político necessitou uma sólida legitimação atemporal que aprovasse a estrutura social existente e, muito importante, a sua privilegiada posição na cúspide dessa sociedade. Nesse sentido, a religião, melhor dizendo, os representantes de uma dada religião, supostamente em direta comunicação com as forças do além - intérpretes infalíveis de textos e de sinais divinos -, outorgavam a necessária legitimação políticosocial ao titular máximo do poder. Em contrapartida, o poder político privilegiava uma dada religião, por vezes proibindo alternativas, a qual se organizava aqui na Terra com os seus sacerdotes e sábios. Tratava-se, pois, da concessão de uma infalível legitimação política - toda vez que os seus argumentos provêm do além ou de textos sagrados -, em troca de proteção social e de poder para redigir e interpretar as leis sociopolíticas próprias do mundo contingente. ${ }^{1}$

Essa relação de dependência entre o poder político e a instituição religiosa ganhou uma força extraordinária tanto nos territórios que aderiram à Reforma como nos que optaram pela Contrarreforma. Trata-se do denominado "konfessionelles Zeitalter", em

\footnotetext{
${ }^{1}$ Este texto responde à conferência que li em maio de 2009 no Colóquio Internacional "Sociabilidades, Poder e Cultura Política", organizado pelo Laboratório Cidade e Poder do Programa de Pós-Graduação em História do Instituto de Ciências Humanas e Filosofia da Universidade Federal Fluminense, Niterói. Agradeço aos organizadores, professores Gizlene Neder e Gisálio Cerqueira Filho, o amável convite. O texto mantém, com algumas mudanças menores, o seu caráter original de conferência.
} 
terminologia germânica, os "tempos confessionais". Se a Igreja, antes da Reforma, podia estar segura dos seus próprios membros em virtude do seu caráter universal, podendo inclusive aceitar uma razoável "confusão teológica", as Igrejas europeias pós-Reforma, entre elas a católica - a única que se considera lgreja por ser herdeira direta dos apóstolos -, tiveram que ativar, pela pressão da concorrência, claros critérios de ortodoxia e de pertença para se caracterizarem como entidades teológicas autênticas. ${ }^{2}$ Essa mudança implicou a necessidade de um maior controle dos seus membros e da observação de certas regras e normas, o que fomentou uma maior "disciplina social".

No marco do processo de consolidação do Estado moderno, oriundo do fim da Idade Média, a vontade política de impor uma determinada "disciplina social”3 não era uma novidade. Variadas medidas fiscais, militares, burocráticas, comportamentais, etc., permitiam maior controle de todos os membros da república e mais efetiva defesa das linhas políticas emanadas do poder. O que caracteriza a Europa dos séculos XVI e XVII, como também Portugal, é que a estreita colaboração entre o trono e o altar fez com que a "confessionalização" teológico-política e a imposição de uma determinada disciplina social se aproximassem mutuamente. A colaboração entre o Estado e a Igreja impunha normas e criava ações e instituições para o seu controle - Inquisição, visitações, etc. -, ao mesmo tempo em que divulgava uma série de valores teológicos de forma muito ativa - por meio de sermões, outros escritos vários, o teatro, etc. - e controlava de forma eficiente todas as etapas da educação, inclusive a Universidade. ${ }^{4} \mathrm{O}$ disciplinamento eclesiástico, como

\footnotetext{
${ }^{2}$ Ver: Reinhard, Wolfgang (1994). "Disciplinamento sociale, confessionalizzazione, modernizzazione. Un discorso storiografico". In Prodi, Paolo / Penuti, Carla (editores), Disciplina dell'anima, disciplina del corpo e disciplina della società tra medioevo ed età moderna, Bologna: II Mulino, p. 101-123, especialmente 108 e seguintes. O conceito de "confessionalização" tem a sua origem na historiografia germânica, especialmente a partir de 1981, com textos assinados por Wolfgang Reinhard e Heinz Schilling: Reinhard, Wolfgang (1981). "Konfession und Konfessionalisierung in Europa". In Reinhard, Wolfgang (editor), Bekenntnis und Geschichte. Die Confessio Augustana im historischen Zusammenhang, München: Vögel, p. 165-189; Schilling, Heinz (1981). Konfessionskonflikt und Staatsbildung. eine Fallstudie über das Verhältnis von religiösem und sozialem Wandel in der Frühneuzeit am Beispiel der Grafschaft Lippe, Gütersloh: Mohn.

${ }^{3}$ Refiro-me ao conhecido conceito de Gerhard Oestreich - Sozialdisziplinierung -, que apareceu publicado por vez primeira em 1969, e que tem sido bastante discutido e comentado desde então: Oestreich, Gerhard (1969). "Strukturprobleme des europäischen Absolutismus". In Oestreich, Gerhard, Geist und Gestalt des frühmodernen Staates. Ausgewählte Aufsätze, Berlin: Duncker \& Humblot, p. 179-197.

${ }^{4}$ Ver: Stolleis, Michael (1995). "Religion und Politik im Zeitalter des Barock. 'Konfessionalisierung' oder 'Säkularisierung' bei der Entstehung des frühmodernen Staates?". In Breuer, Dieter (editor), Religion und Religiosität im Zeitalter des Barock, Wiesbaden: Harrassowitz, p. 23-42. Sobre a importância do sermão como meio de propaganda e consolidação do poder político ibérico, ver, entre outros: Álvarez-Ossorio Alvariño, Antonio (2002). "La sacralización de la dinastía en el púlpito de la Capilla Real en tiempos de Carlos II". In Criticón, n. 84-85, p. 313-332; Negredo del Cerro, Fernando (2002). "La palabra de Dios al servicio del Rey. La legitimación de la Casa de Austria en los sermones del siglo XVII". In Criticón, n. 84-85, p. 295-311; e Rodrigues-Moura, Enrique. (2007). "Abraham a Sancta Clara, Paravicino y Vieira. Apud Europaeos et Occidentales populos". In Danler, Paul et alii (editores.), Österreich, Spanien und die europäische Einheit / Austria, España y la unidad europea. XI. Spanisch-Österreichisches Symposium. Innsbruck: Innsbruck University Press, 3-34.
} 
parte do mais amplo disciplinamento social, tinha uma componente interna que punha grande ênfase na confissão, e uma componente externa que incluía, além da Inquisição e das visitações, também outras instituições como as Misericórdias ou diferentes confrarias ou agrupamentos religiosos. Essa colaboração permitia que as regras e modelos emanados do Paço de Lisboa alcançassem as mais longínquas regiões do Reino e conquistas.

A “razão de estado" do século XVII propunha o apoio político a uma determinada Igreja e, ao mesmo tempo, instrumentalizava essa lgreja para os processos de inclusão e lealdade que ampliavam e aprofundavam o seu domínio efetivo no Reino. ${ }^{5}$ De forma paralela, o poder político punha em andamento processos de exclusão de outras formas de religiosidade, nomeadamente, no caso português, dos cristãos-novos. Por sua vez, a Igreja conseguia que se afirmasse o seu monopólio teológico, ganhava importantes benefícios econômicos e angariava não poucos privilégios da mais variada índole: honoríficos, militares, jurídicos, fiscais, etc.

Segundo a maioria dos escritos políticos portugueses do Ancien Régime, o poder provinha de Deus através do povo que escolhera na origem do Reino uma dinastia para governar a sociedade e evitar que os maus e ímpios dominassem sobre os justos. Nesse sentido, o rei tinha que respeitar os foros, direitos e privilégios dos diferentes grupos que conformavam o Reino, estabelecendo com eles uma estreita relação clientelar, paternofilial, que exigia um delicado equilíbrio que nem sempre era fácil de manter. O poder do rei não era absoluto, ilimitado, pois estava obrigado a se submeter às leis. Segundo um dito muito comum na época, "El Rei aonde póde, \& não aonde quer". ${ }^{6}$ Se o rei não respeitasse essas regras, transformar-se-ia em um tirano; se fosse o povo que não as respeitasse, que não fosse fiel vassalo do rei: surgiria o perigo da rebelião, do caos.

Até aqui, uma mais que sucinta descrição da forma em que se estabeleceram as relações entre o poder político e a religião na Primeira Idade Moderna, especialmente do

\footnotetext{
${ }^{5}$ Não é objetivo desta conferência discutir as muitas e profundas diferenças que surgiram entre o Estado e a Igreja. Conflitos existentes antes e depois da Restauração e que vinham à tona pelos mais variados motivos: tributos, reconhecimento da nova dinastia portuguesa por parte da Santa Sé, etc. Devo salientar que não parto, em absoluto, de uma visão idealista que acredita numa real divisão entre ambas as instituições, pois a interpenetração era sumamente importante e real. Como já foi assinalado, não se tratava de dois corpos com competências perfeitamente delimitadas e separadas. Ver: Paiva, José Pedro (2000). "A Igreja e o Poder". In Marques, João Francisco / Gouveia, João Camões, História Religiosa de Portugal. Volume 2. Humanismos e Reformas, Lisboa: Círculo de Leitores, p. 135-185; e Paiva, José Pedro (2007). "El Estado en la Iglesia y la Iglesia en el Estado. Contaminaciones, dependencias y disidencia entre la monarquía y la Iglesia del reino de Portugal (1495-1640)". In Manuscrits, n. 25, p. 45-57.

${ }^{6}$ Esse dito teve especial vigência na política portuguesa de Seiscentos, ver: Xavier, Ângela Barreto (1998). "El Rei aonde póde, \& não aonde quer". In Razões da Política no Portugal Seiscentista, Lisboa: Colibri. Ver também: Hespana, António M. (1994). As Vésperas do Leviathan. Instituições e poder político. Portugal, século XVII, Coimbra: Almedina.
} 
ponto de vista da monarquia católica portuguesa. Adiante, farei uma breve análise dos argumentos utilizados para legitimar a Restauração portuguesa, com o propósito de analisar a sua estrutura expositiva básica e, em consequência, apresentar uma proposta de interpretação narrativa de caráter geral e abrangente da múltipla casuística. Mostrarei a importância do elo de ida e volta que se estabeleceu entre o poder político e o poder religioso - relação própria dessa época histórica confessional -, e que tinha como objetivo divulgar os argumentos da Restauração, ao tempo que se propagava pelo Reino um determinado modelo de disciplina social. Por último, defendo que, da mesma forma em que os Habsburgo cultivaram a denominada pietas austriaca, os Bragança se apropriaram de uma pietas mariana já existente, com a intenção de justificar e consolidar a sua legitimidade política.

A morte e o desaparecimento do jovem rei português D. Sebastião, em 1578 e em solo africano, decapitou a coroa portuguesa. Imediatamente, Filipe II de Espanha, da dinastia dos Habsburgo ou dos Áustrias, exigiu os seus declarados legítimos direitos ao trono português. As pretensões de Filipe II não eram absolutamente infundadas, afinal de contas, era parente do falecido e desaparecido D. Sebastião. Ambos eram netos de D. Manuel I, sendo que D. Sebastião por via masculina (D. João III) e Filipe II por via feminina (Isabel de Portugal). Outros nomes também entraram na disputa, entre eles Antônio de Portugal, o Prior do Crato, ${ }^{7}$ e a Duquesa de Bragança, D. Catarina. ${ }^{8}$ No entanto, em um primeiro momento optou-se por uma solução nacional, portuguesa: o cardeal D. Henrique, filho de D. Manuel I, foi aclamado rei. O já sexagenário D. Henrique teve que renunciar à púrpura de cardeal, com o intuito de garantir a continuidade da dinastia de Avis no trono português. Não teve sorte, pois faleceu dois anos depois, em 1580, sem descendência. Assim, Filipe II de Espanha soube fazer valer o seu parentesco, a sua força militar e a sua capacidade de persuasão econômica. Nas Cortes de Tomar, em abril de 1581, com o nome de Filipe I de Portugal, ele assumiu a titularidade da coroa portuguesa, ampliando ainda mais os territórios da denominada monarquia compósita. ${ }^{9}$

\footnotetext{
${ }^{7}$ Também neto de D. Manuel I, pois era filho ilegítimo do infante D. Luís.

${ }^{8}$ Segunda filha do infante D. Duarte, outro dos filhos de D. Manuel I, logo, herdeira do trono por via masculina, argumento dinástico fundamental para a Restauração.

${ }^{9}$ Nesta denominada monarquia compósita o rei apresentava-se como o nexo de união entre os diferentes territórios sob o seu domínio - reinos, principados, províncias, etc. -, sem existir, no entanto, uma real união política das leis e do aparato do Estado, excetuando os territórios adquiridos por conquista. Ver: Elliot, John H. (1992). "A Europe of Composite Monarchies". In Past \& Present, n. 137, novembro, p. 48-71. Como já assinalará John $\mathrm{H}$. Elliot, o modelo da monarquia compósita espanhola seguia as linhas jurídicas traçadas por Juan de Solórzano y Pereira em 1647: "Los Reinos se han de regir y gobernar como si el Rey que los tiene juntos, lo fuera solamente de cada uno de ellos." Solórzano y Pereira, Juan de (1972). Política indiana, tomo III, Madrid: Biblioteca de Autores Españoles, vol. CCLIV, p. 301 (livro 4, capítulo 19, parágrafo 37).
} 
Esse ano de 1581 marca o fim da dinastia portuguesa de Avis, pois a Casa de Áustria incorporou aos seus já vastos domínios a monarquia portuguesa, com todos os seus territórios: Portugal, Estado do Brasil e praças africanas e asiáticas.

Umas cortes em Tomar perante os representantes dos três estados e uma entrada triunfal em Lisboa não eram acontecimentos suficientes para consolidar a nova dinastia, máxime quando a partir de 1583 Filipe I de Portugal passou a ser um "rei ausente". Era necessária a colaboração institucional da Igreja, da sua capacidade de divulgar e impor disciplina social, sempre na linha normativa do Concílio de Trento. Em uma Carta geral edital (1582) do Arcebispo de Braga podemos ler que, para a "melhor conservação" da "quietação, paz e sossego destes Reinos" se exige ao clero que advirta a admoeste ao povo que "sua Majestade [D. Filipe I] é Rei e senhor natural e legítimo destes seus reinos por ser neto Del Rei Dom Manuel" e por ter sido "jurado sua Majestade em cortes gerais por seu Rei e senhor natural, como o fizeram em Tomar". ${ }^{10}$ A relação paterno-filial, fundamental para o corpo místico da república, mantinha-se: "sua Majestade é pai de seus vassalos e trata os Portugueses como a verdadeiros filhos e vassalos mui leais." 1 Lembre-se que o sermão possuía um poder disciplinador que não deve ser em absoluto menosprezado. No seu Discurso político (1628) sobre o modo como se devia predicar, Antônio Carvalho de Parada alinha sem dúvida alguma o governo espiritual das almas ao governo temporal da República e afirma que, se um predicador expõe que não há justiça no Reino e que tudo são desordens, está desautorizando o governo e pondo em grave perigo o bem comum. O predicador possui estatuto de auctoritas durante o sermão, pois tem ante si "un auditorio público en que todos callan y oyen con respeto, creyendo todo lo que el predicador dice”. Ele deve estar atento ao que diz, pois, ao repreender os príncipes e as suas faltas, e levando em consideração o "fervor de sus palabras", pode provocar um

\footnotetext{
${ }^{10}$ Meneses, João Afonso de (1582). Carta geral edital. 20 de dezembro. (Sem lugar de impressão). Trata-se de um documento de três páginas não numerado e digitalizado pela Biblioteca Nacional de Lisboa: http://purl.pt/14941 (acessado por última vez em 15 de março de 2010). Moderniza-se a ortografia e, parcialmente, a pontuação, tanto aqui como nas demais citações. Esse apoio da Igreja à união com Castela não impediu que houvesse um forte movimento autonomista entre os próprios membros do clero, fundamental para manter na memória coletiva a lembrança de um reino português independente e perdido. Ver: Marques, João Francisco (2010). A parenética portuguesa e a dominação filipina, Lisboa: Imprensa Nacional-Casa da Moeda.

${ }^{11}$ Ibidem. Ver também: Cardim, Pedro (2001). "Religião e ordem social. Em torno dos fundamentos católicos do sistema político do Antigo Regime". In Revista de História das Ideias, vol. 22, p. 133-174; e Cardim, Pedro (1999). "Amor e amizade na cultura política dos séculos XVI e XVII". In Lusitânia Sacra, segunda série, n. 11, p. 21-57.
} 
motim ou rebelião. ${ }^{12}$ Por isso, conclui Carvalho de Parada, não convém repreender o príncipe em público.

Essa união do Reino de Portugal e conquistas à herança dinástica dos Habsburgo teve uma existência de 60 anos, até que no dia primeiro de dezembro de 1640 iniciou-se o que a historiografia portuguesa da época e a hodierna denominam de Restauração, levantamento político que entregou a coroa lusa à família dos Duques de Bragança. $\mathrm{O}$ seu titular, D. João, oitavo Duque de Bragança, passou a reinar em Portugal com o nome de D. João IV. Temos, no caso histórico da Restauração portuguesa, um levantamento político, inclusive militar - lembrem-se dos 28 anos de guerras intermitentes, até a definitiva Paz de 1668 -, em um país católico e contra um monarca católico; neste caso Filipe IV de Espanha, que cumpria e fazia cumprir nos seus domínios os preceitos religiosos mais ortodoxos emanados do Concílio de Trento. De acordo com o paradigma ideológico dominante, tratava-se de algo inaceitável. Levantar-se contra o monarca natural e católico, a quem os três estados haviam prestado juramento nas Cortes de Lisboa de 1619, significava o mesmo que agir contra o bem comum estabelecido por vontade divina. ${ }^{13}$

Como legitimar uma mudança política no Ancien Régime, quando ambos os adversários, Castela e Portugal, coincidiam ideologicamente em que o rei era uma pessoa eleita pelo braço divino? Como se levantar legitimamente contra o rei natural e eleito em cortes pelos três estados? Como explicar ideologicamente a Restauração? Que narrações se construíram para argumentar e justificar, considerar legítimo, o grave ato de desobediência? Essas perguntas retóricas aqui lançadas não são mais do que uma variante das que, no seu momento, a própria propaganda restauradora tentou responder por extenso em inumeráveis textos e em várias línguas, nomeadamente português, castelhano e latim. ${ }^{14}$

Vejamos a formulação dessas perguntas nas palavras de Antônio Pais Viegas, no seu Manifesto do Reino de Portugal (1641): "Aclamou Portugal subitamente Rei, reconhecendo até agora outro. Pode-se perguntar, que direito teve para o fazer? $E$ o [sic]

\footnotetext{
${ }^{12}$ Parada, Antônio Carvalho de (1628). Discurso político. Fundado en la Doctrina de Cristo nuestro Señor, $y$ de la Sagrada Escritura. Si conviene al gobierno espiritual de las almas o al temporal de la República, aprobarse el modo de predicar de reprehender a los Príncipes y Ministros, Lisboa: Pedro Craesbeeck, f. 6 verso, 7 frente e 10 frente.

${ }^{13}$ Os três estados presentes nas Cortes de Tomar de 1581 prestaram juramento a Filipe I de Portugal (Filipe II) e ao seu herdeiro, Diogo Félix de Áustria (que viria a falecer em 1582). Os mesmos três estados, já nas Cortes de Lisboa de 1619, prestaram juramento a Filipe II de Portugal (Filipe III) e ao seu herdeiro, o futuro Filipe III de Portugal (Filipe IV).

${ }^{14}$ Ver: Torgal, Luís Reis (1981-1982). Ideologia política e Teoria do Estado na Restauração, dois volumes, Coimbra: Biblioteca Geral da Universidade, p. 121 e seguintes.
} 
em que se fundou o mesmo Rei para aceitar? Juntamente que causas houve para mudança tão repentina?"15 As respostas encontram-se no mais que assinalável poder de persuasão das diferentes narrativas de legitimação política. Deter-me-ei um pouco na ideia de narração para explicar a sua importância argumentativa, a sua capacidade de convicção, o seu valor legitimador, o seu poder simbólico e a sua grande potencialidade para estruturar o conhecimento e os saberes do mundo empírico. ${ }^{16}$

Partindo das teorias formalistas russas, do denominado construtivismo radical e do mais recente narrativist turn, considero a narração a operação mais elementar do ser humano - consciente ou inconsciente - encaminhada a criar significados, tanto para comunicá-los como para percebê-los. Uma narração vem a ser um modelo de organização com a capacidade de gerar e divulgar conhecimentos e que oferece ao produtor ou receptor (leitor ou ouvinte) uma orientação e valor semântico do presente, do passado e dos possíveis mundos fictícios. Uma narrativa apresenta uma história (histoire) estruturada em várias sequências ou unidades que se organizam de acordo a um discurso (discours), o qual incorpora o tempo (analepse, prolepse, in medias res, etc.) como uma de suas categorias fundamentais. A histoire e o discours unem-se em um ato de fala concreto ou fingido que inclui um lugar, um tempo de partida e uma determinada duração.

Uma narração vem a ser a forma mais familiar, mais comum, que temos os seres humanos para transmitir nossas experiências originadas no denominado mundo empírico, exterior à própria narração. Para a inter-compreensão de uma narrativa determinada temos que partir da suposição de que entre produtor e receptor(es) existe um necessário mínimo denominador comum de conhecimentos e de experiências socioculturais compartilhados. Só dessa forma haverá uma intercomunicação de significados. É necessária, pois, uma certa inter-subjetividade na hora de formar, receber e assimilar narrações produtoras de significados. Em definitiva, o que um narrador ou produtor de narrativas faz é pôr ordem no mundo, e para isso escolhe - ou constrói - aqueles fatos ou episódios que considera mais pertinentes e os associa em sequências, enfatizando ou não as cadeias de causalidades. O narrador também pode intervir na narrativa e comentá-

\footnotetext{
${ }^{15}$ [Viegas, Antônio Pais] (1641). Manifesto do Reino de Portugal. No qual se declara o direito, as causas e o modo que teve para eximir-se da obediência Del Rey de Castela e tomar a voz do Sereníssimo Dom João IV do nome e XVIII entre os Reis verdadeiros deste Reino, Lisboa: Paulo Craesbeeck, f. 2 frente.

${ }^{16}$ Tenho em consideração, no marco da narratologia (narratology), textos com um caráter, a priori, não ficcional. Ver: White, Hayden (1978). "The historical text as literary artifact". In White, Hayden, Tropics of Discourse. Essays in cultural criticism, Baltimore / London: The Johns Hopkins University Press, p. 81-100; Wertsch, James V. (2002). Voices of Collective Remembering, Cambridge: Cambridge University Press; e Kindt, Tom / Müller, Hans-Harald (editores) (2003). What Is Narratology? Questions and Answers regarding the Status of a Theory, Berlin / New York: Walter de Gruyter.
} 
la. Tanto o produtor como o receptor precisam ativar a sua "imaginação construtiva" (Collingwood) para que uma determinada serialização de micronarrativas, sequências ou episódios adquiram coerência e verossimilhança. Digamos que, do ponto de vista do construtivismo radical, não há uma suposta realidade se não houver um relato que a organize, pois o ser humano precisa da narrativa para compreender e captar a intangível realidade. Narrar é uma atividade com raízes antropológicas e serve para oferecer claridade expositiva e de compreensão no ato de tentar compreender, na medida do possível, a complexidade do mundo exterior. Ao mesmo tempo, o ato de gerar uma narrativa, ou de compreender e assimilar cognitivamente uma sequência de fatos ou de episódios caracterizados como uma narrativa, implica uma redução da complexidade desse mundo que se pretende dominar conscientemente. Cada narrativa implica, em potência, uma função metafórica, simbólica, isto é, de múltiplos significados, que permite avançar, sincrônica e diacronicamente, uma explicação semântica das ações descritas, realizadas ou planejadas; ou simplesmente de ações em grau especulativo.

De acordo com as já quase centenárias investigações formalistas, uma narração possui uma estrutura facilmente compreensível: início, meio e fim. Possui também um conflito, que deve ser superado e, uma vez superado, ou não, há uma mudança do estado inicial: prêmio, castigo ou inclusive outras opções. Qualquer narrativa pode ser, por isso, consciente ou inconscientemente, analisada estruturalmente. A organização dos elementos micronarrativos ou episódios de uma narração podem mudar de lugar compositivo (discours) e com isso existe a possibilidade de que se altere o significado. Mas não só. Uma mesma narrativa pode ser interpretada de forma divergente, pois cada uma delas possui inerentemente uma potencialidade de significados. Cada época histórica, ou, melhor dito, as vozes autorizadas de cada época histórica estabelecem o significado canônico das narrativas que estruturam uma sociedade, que organizam a sua memória coletiva desde o poder dos discursos hegemônicos. Assumindo que uma narrativa, como já foi dito, possui um começo, um meio e um fim - caso contrário estaríamos perante episódios isolados, não organizados, portanto, sem estrutura narrativa -, o receptor sabe, sente que uma narrativa se encaminha a um fim. De não ser assim, a transmissão de informação sofreria uma falta de continuidade. A comunicação se interromperia. Toda narrativa possui o que se denomina de "poder de conclusão", que, obviamente, não está presente no mundo empírico, pois este é alheio à codificação narrativa. Em palavras de Wertsch, o "process of emplotment" e o "sense of an ending" são elementos estruturantes de uma narração e permitem visualizar mentalmente esse 
começo, meio e fim para, só assim, outorgar significados, aventurar uma interpretação do apreendido. Além dessa estrutura da narração, o meio de comunicação resulta fundamental. Uma narrativa apresenta uma determinada codificação e o receptor, para entender essa narrativa e o eventual significado, tem que decodificá-la previamente.

O crítico James V. Wertsch propôs recentemente a distinção entre "specific narratives" e "schematic narrative templates". As primeiras fornecem datas e fatos concretos, logo, mais ou menos controláveis e de difícil - mas não impossível falsificação. As segundas são mais gerais e possuem uma estrutura mais esquemática, sem fornecer informação precisa, facilmente verificável, servindo, sobretudo, como subtexto estrutural com alto potencial de polissignificação: quer dizer, podem gerar inumeráveis interpretações concretas, podem ser reinterpretadas, uma e outra vez, de acordo com o momento histórico. Wertsch baseia a sua proposta, do ponto de vista cognitivo, em teóricos como Frederic Charles Bartlett, especialmente no seu livro Remembering: a study in experimental and social psychology (1964), no qual se defende que a cognição humana deve ser entendida mais como um processo construtivo, feito pelo agente, pelo indivíduo, do que como um produto de estímulos provindos do mundo empírico. Quer dizer, na interação sujeito e mundo referencial, Bartlett põe muito peso, o fundamental, na construção elaborada pelo sujeito, tanto dos supostos fatos como da histoire e do discours. ${ }^{17}$

Quando o poder hegemônico fornece uma narrativa, há um discurso elaborado, uma história com uma evidente função volitiva de construção da denominada realidade. Não se pode entender nenhuma sociedade sem um conjunto básico de narrativas, que podem variar no decorrer da história, mas nunca deixam de existir. Essas narrativas podem ser referenciais, com o potencial de se referir a fatos, caracteres ou eventos, ou podem ser dialógicas, portanto, com grande e principal interação entre elas, entre as narrativas já disponíveis em uma determinada sociedade. São essas narrativas

\footnotetext{
17 Vindo ao Brasil, há três dias (25 de maio de 2009), no avião, pude ler um artigo assinado pelo jornalista Benedict Carey que mostrava a imensa utilidade e atualidade que o estudo das narrações tem no momento presente. Devido à necessidade de encontrar um "filtro de honestidade" nos interrogatórios policiais, diversos estudos teriam demonstrado que "as pessoas que inventam uma história em geral preparam um roteiro rígido e sem detalhes", enquanto as "pessoas que dizem a verdade não têm roteiro e tendem a recordar detalhes mais estranhos e até a cometer erros". Ver: Carey, Benedict (2009). "Discurso, e não trejeito, pode revelar a verdade". In The New York Times versão para a Folha de São Paulo, 25 de maio, p. 5. Guardem-se as distâncias históricas mais que necessárias com os fatos referidos nesta conferência: interessa-me salientar que uma narração legitimadora de um ato determinado tem que ser encarada também como um ato de ficção e não só como uma suposta exposição fiel de fatos empiricamente acontecidos.
} 
hegemônicas, na linha das "schematic narrative templates", que finalmente ocupam um espaço na memória coletiva.

Tendo em conta esse breve resumo sobre a importância de uma narrativa para a transmissão de significados, a estrutura básica (histoire) do discurso legitimador da Restauração seria a seguinte, de acordo com uma narração linear:

1) Portugal florescente, antes do domínio da Casa de Áustria.

2) União com Castela como momento de aguda crise ou cesura radical com esse passado idealizado.

3) Tempo de cativeiro, expiação e confiança na Providência durante os sessenta anos de dominação castelhana.

4) Libertação triunfante e pacífica do jugo castelhano, ou Restauração propriamente dita.

5) Promessa jubilosa de um tempo de felicidade futura para Portugal.

São cinco pontos que assinalam três momentos temporais: passado prestes a tornar-se remoto, pela perda da sua memória no presente (ponto 1); passado recente (3); e imediato futuro (5). Assinalam também duas rupturas: crise de matriz decadente (2); e crise de matriz jubilosa (4). ${ }^{18}$ Os pontos 4) e 5) costumam aparecer, do ponto de vista narrativo, quase como uma unidade, mais ou menos coincidentes no tempo, no sentido de que a aclamação real implica, obrigatoriamente, um futuro que a partir desse mesmo instante passa a recuperar uma perdida idade dourada. Tanto é assim que, nos primórdios do governo de D. João IV, Antônio Carvalho de Parada escreveu que estava

\footnotetext{
${ }^{18}$ Fernando Bouza Álvarez, citando uma sugestão de José Cepeda Adán, já propôs uma narrativa muito semelhante: "Como otros muchos estados nuevos, la Restauração satanizó el pasado inmediato que venía a cambiar el antiguo esplendor e idealizó el futuro gobierno", ver: Bouza Álvarez, Fernando Jesús (1986). "«Clarins de Jericho». Oratoria sagrada y publicística en la Restauração portuguesa". In Cuadernos de Historia Moderna y Contemporánea, vol. 7, p. 21. A seguir, nesse mesmo texto, Bouza Álvarez aponta uma fonte histórica que, pelas suas palavras, já tinha percebido a estrutura narrativa da Restauração: "Criticando esta actitud, el autor de una Relación de las Cortes primeras del Duque de Bragança decía que el fundamento de su éxito estaba en que «es natural en los pueblos venerar y alabar todo lo passado... mirar con poca efición lo presente, acordados de qualquier mal... y esperar temerariamente felicidades futuras, siempre inciertas»" (Ibidem). Bouza Álvarez explicou a "narrativa" da Restauração da seguinte forma: "Por una parte, la nación lusitana se restaura a su estado primitivo y época dorada, el mundo feliz de los Avís del siglo XVI, devolviendo a los verdaderos sucesores de aquellos reyes lo que era suyo y que les había sido arrebatado en 1580; por otra, el país se restaura definitivamente a su esencial condición de 'reino por sí'. Como en el caso de la revolución inglesa, se juega también aquí con la pureza de una 'vieja constitución' que hubo que recuperar." Ver: Bouza [Álvarez], Fernando Jesús (1991). "Primero de diciembre de 1640.: ¿una revolución desprevenida?". In Manuscrits, n. 9, p. 208.
} 
"reverdecendo neste nosso Reino a idade de ouro tão desejada dos antigos e de que tanto disseram aqueles a quem Deus fez mercê de revelar a felicidade presente."19

Do meu ponto de vista, todos os textos dos publicistas favoráveis à Restauração encaixar-se-iam no marco dessa estrutura narrativa aqui apontada, sem menoscabo de que alguns desses escritos jurídico-políticos insistam em um ou outro detalhe ou dediquem maior ênfase a um momento específico, mas sempre tendo em consideração que o seu público conhecia e, às vezes, partilhava essa estrutura narrativa básica. Ainda é necessário notar que esta proposta narrativa apresenta uma contingência histórica muito evidente. Quer dizer, embora os cinco pontos básicos assinalados possam ser úteis ainda hoje, a significação de cada um deles tem sofrido importantes variações no decorrer dos séculos. Por exemplo, as comemorações da Restauração que se organizaram por volta de 1940 propunham, como é óbvio pensar, outra interpretação semântica dos atores: rei, fidalgos, nobreza, povo, castelhanos, etc.

Duma perspectiva que tenha em consideração não tanto a estrutura mas o próprio conteúdo das narrativas da Restauração - e, mesmo assim, sempre tentando manter um caráter abrangente de interpretação -, observam-se duas grandes linhas argumentativas, ambas em torno do conceito de legitimidade jurídico-política, quer dizer, do que é justo e necessário:

1) ilegitimidade de origem e ilegitimidade no exercício do poder da dinastia dos Habsburgo no trono de Portugal.

2) legitimidade de origem e legitimidade no exercício do poder da dinastia dos Bragança no trono de Portugal.

A primeira linha, que condena a presença castelhana no trono do Reino de Portugal, está formada por sequências narrativas que defendem uma ilegitimidade na origem do reinado de Filipe I de Portugal e seus sucessores, assim como por episódios narrativos que defendem uma ilegitimidade no exercício do poder. Trata-se da denominada "dupla tirania dos monarcas espanhóis (por título de aquisição e por

\footnotetext{
${ }^{19}$ Parada, Antônio Carvalho de (1643). Arte de reinar. Ao potentíssimo Rei D. João IV nosso Senhor Restaurador da liberdade portuguesa. Bucelas: Paulo Crasbeck, primeiro fólio da dedicatória. Já em 1621, como assinala João Francisco Marques, Pedro Calvo lembrou em sermão proferido na Sé de Lisboa "os antigos brios, a idade de ouro de Portugal". Ver: Marques, João Francisco (2010). Op. cit., p. 197. Ver também: Marques, João Francisco (1989). A parenética portuguesa e a Restauração, 1640-1668. A Revolta e a Mentalidade, 2 vols., Porto: Instituto Nacional de Investigação Científica, vol. II, p. 181-182.
} 
administração)". ${ }^{20}$ A segunda linha, complementária da primeira, afirma, por sua vez, a legitimidade de origem, dinástica, do governo dos Bragança e, muito importante, projeta no futuro um tempo de felicidade para a nação portuguesa governada por D. João IV, logo, legitima o futuro exercício do poder. Obviamente, os publicistas combinam criativamente nos seus textos essas duas linhas argumentativas no marco estrutural da narração antes assinalada - Portugal florescente, união com Castela, tempo de cativeiro e expiação, libertação do jugo castelhano e promessa de felicidade futura -, pois o objetivo era convencer, movere. ${ }^{21}$

Estabelecidos os parâmetros estruturais da narrativa da Restauração, interessava a sua divulgação no exterior para o reconhecimento de um Portugal independente por parte de outros países, mas também no interior, para preservar a harmonia social que exigia a "razão de estado" católica própria do Ancien Régime. A melhor forma de legitimar convincentemente em todo o Reino a instauração de uma "Lei Nova"22 (Vieira dixit), uma nova dinastia no trono de Portugal, era por meio da Igreja católica, autoridade infalível e com representantes dispersos por todos os domínios de Portugal. Nesse sentido, a narrativa básica da Restauração frisou de inúmeras maneiras que a feliz restituição de Portugal não teria sido possível sem os "auxílios divinos [...] os quais a poderosa mão de Deus facilitou", como escreveu Antônio Pais Viegas no seu Manifesto do Reino de Portugal. $^{23}$

A religião católica, com a sua infindável cópia de historias bíblicas razoavelmente conhecidas e com outras narrações de origem medieval - devoção eucarística, devoção mariana, vida de santos, etc. -, oferecia um ótimo acervo narrativo para legitimar a Restauração. ${ }^{24} \mathrm{O}$ sólido fundo cultural do sebastianismo e a muito divulgada concepção ${ }^{20}$ Calafate, Pedro (2001). "A reflexão portuguesa sobre a política nos séculos XVI e XVII". In Calafate,
Pedro (direção), História do Pensamento Filosófico Português. Volume II. Renascimento e Contra-Reforma,
Lisboa: Caminho, p. 685 . Mais por extenso sobre a "tirania de facto e de exercício", ver: Marques, João
Francisco (1989). Op. cit., vol. II, p. $31-83$.
${ }^{21}$ João Fernando Marques enumera, citando um sermão de frei Thomas Aranha (1645), as cinco pedras
que D. João IV (David) teria usado contra o rei castelhano (Golias): usurpação sucessória, retenção por
meios violentos, violação dos foros, desmando nos tributos e falta de consideração pelo assento das Cortes
de Lamego. Ver: Marques, João Francisco (1989). Op. cit., vol. II, p. 27 .
${ }_{22}$ Vieira, Antônio (2003). "Sermão dos Bons Anos". In Vieira, Antônio, Sermões, tomo 2, São Paulo: Hedra,
p. $363-384$. Sermão proferido na capela real em 1641 e publicado em 1642 .
23 [Viegas, Antônio Pais] (1641). Op. Cit., f. 37 verso.
24 Lembre-se, por exemplo, que o programa teológico do Concílio de Trento fomentou a proliferação de
"Vidas exemplares", pelo seu caráter didático, moralizador e pedagógico. Uma forma muito efetiva de
disciplina eclesiático-social. E as missas, segundo a sessão XXII (1562) do Concílio de Trento, tinham que
favorecer certos ritos e uma cenografia adequada, sinais visíveis, para atrair os ânimos dos fieis que,
considerava o Concílio, por sua intrínseca natureza podiam ter dificuldade para meditar sobre coisas divinas
sem o auxílio de elementos materiais. A religião católica oferecia, pois, um marco referencial e de
significados conhecidos e partilhados por todos, onde se podiam inserir facilmente e de forma 
messiânica de Portugal como povo eleito por Deus facilitou a difusão e a vasta aceitação das mais variadas profecias sobre a vinda de D. Sebastião e, principalmente, da vinda de tempos melhores. Francisco Manuel de Melo descreveu com precisão a importância do sebastianismo: "Corria já de sessenta anos entre os portugueses uma opinião ou seita civil que a muitos teve crédulos em que vivia peregrinando pelo mundo El-Rei $D$. Sebastião. Estes eram com nome alegre os amados sebastianistas. Estendeu-se não só aos antigos vassalos, mas se deduziu a filhos e netos cujo engano compreendia homens virtuosos e sábios. $^{25}$

Como a dinastia da Casa de Áustria se definia pelo seu zelo religioso, não muitos foram os possíveis ataques à sua falta de fé, embora sim se relatassem algumas profanações de templos religiosos por parte das tropas castelhanas que entravam em Portugal, concretamente, no Alentejo. ${ }^{26}$ Por isso, mais do que uma narrativa contra uns hipotéticos Áustrias não católicos, informação que não teria um sólido grau de verossimilhança e não condizia com a "razão de estado" católica, era mais útil a armação de uma narração defensora do primeiro de dezembro de 1640 e dos Bragança em formato afirmativo. ${ }^{27}$

A caminho da conclusão, comentarei duas narrativas de caráter não bíblico muito difundidas que apareceram logo nos primeiros dias da Restauração, no mesmo mês de dezembro de 1640: a aclamação de D. João IV pelo afamado braço do Cristo crucificado e a apropriação da pietas mariana para a causa bragantina. Ambas as histórias são bastante conhecidas pela historiografia. Interessa-me mostrar, aqui, a sua estrutura narrativa, em perfeito encaixe no marco dos processos legitimadores da Restauração antes enumerados. Em ambos os casos, trata-se da intercessão divina - o braço de Cristo e a intervenção da Virgem Maria - que permite superar jubilosamente uma situação

compreensível uma ampla série de narrativas político-religiosas, cuja função era a de legitimar a Restauração.

${ }^{25}$ Melo, Francisco Manuel de (1995). Tácito Português. Vida, Morte, Ditos e Feitos de El Rey Dom João IV de Portugal, Lisboa: Sá da Costa, p. 62.

${ }^{26}$ A acusação de heresia fazia parte dos discursos políticos da época. Domingos Pereira Bracamonte ironizou sobre o assunto: "Los Castellanos, como no pueden tragar bien nuestra libertad, desahogan con nos llamar judíos rebelados (que siempre trataron de nos herir, más con la lengua que con la espada), mas Ilamennos lo que quisieren, con tanto que no nos llamen Castellanos", ver: Bracamonte, Domingos Pereira (1642). Banquete que Apolo hizo a los embajadores del Rey de Portugal Don Juan Cuarto. En cuyos platos hallarán los señores convidados, mezclada con lo dulce de alguna poesía y política, la conservación de la salud humana, Lisboa: Lourenço de Amberes, p. 156.

${ }_{27}$ Veja-se a prudência que exibe Francisco Brandão no seu Discurso gratulatório sobre o dia da felice Restituição (1642), quando elogia D. João IV sem criticar Filipe IV de Castela: "Quem negará ser o melhor dia de Portugal o primeiro de Dezembro, em que se viu sujeito a Vossa Majestade [D. João IV] e livre do governo Del-Rei D. Felipe IV de Castela? Não digo que se viu livre Portugal então de um mau Príncipe, porque o decoro, que se deve às Majestades, o não permite, nem as excelências pessoais Del-Rei Católico poderão nunca ser menoscabadas." Brandao, Francisco (1642). Discurso gratulatório sobre o dia da Felice Restituição e Aclamação da Majestade Del-Rei D. Joao IV N.S., Lisboa: Lourenço de Anveres, p 4-5. 
de cativeiro ou expiação - a dominação filipina -, pois o protagonista, segundo a história narrada, nunca duvidou da Providência. Em prêmio por sua paciência, o braço de Cristo confirma a eleição do novo rei. Por sua vez, a Virgem Maria intercede junto a Deus a favor do povo português e, ao mesmo tempo, oferece proteção e amparo nos tempos difíceis dos anos seguintes a 1640. Ambas as narrativas foram copiosamente repetidas e divulgadas e, sempre que possível, performativamente atualizadas. ${ }^{28}$

Os inescrutáveis desejos divinos ganharam uma narrativa visível com a lenda do braço de Cristo, acrescida por sua forte capacidade de convicção. Tudo aconteceu no próprio dia primeiro de dezembro de 1640, na parte da manhã. Com o intuito de acalmar o povo que, no mínimo, estava surpreso com o movimento de tropas, o arcebispo D. Rodrigo da Cunha saiu, segundo conta Nicolau da Maia de Azevedo (1641), "a pé com cruz alçada, acompanhado da maior parte do clero. ${ }^{29}$ Mais adiante, conseguida a bandeira da cidade que se guardava no Senado da Câmara, "começou o povo todo inquieto e descomposto a gritar, dizendo que uma imagem de Nosso Senhor Jesus Cristo que estava cravada na cruz que ia diante do senhor arcebispo não somente havia despregado a mão direita, mas que também a havia dobrado - como que queria botar a bênção a tudo o que estava feito. ${ }^{30}$ Imediatamente o acontecimento foi reconhecido como milagre e obra de Deus, que legitimava a aclamação. ${ }^{31}$

\footnotetext{
${ }^{28}$ Por exemplo, quando D. João IV partiu para a campanha militar do Alentejo, a 19 de julho de 1643 , levou consigo a imagem do Senhor cujo braço se desprendera no dia da aclamação. Ou, no caso da Virgem Maria, quando finalmente, em 1648, foram interditas as moedas castelhanas e se tomou a decisão de cunhar moedas de ouro e prata com a imagem de Nossa Senhora da Conceição.

${ }_{29}$ [Azevedo, Nicolau da Maia de] (2007). Relação de tudo o que passou na Felice aclamação do mui alto e mui poderoso rei dom João o IV nosso senhor, cuja Monarquia prospere Deus por largos anos, Coimbra: Faculdade de Letras da Universidade de Coimbra, p. 19.

${ }^{30}$ Ibidem, p. 20. Interessa notar que, neste caso, o povo não está tranquilo, como na maioria das outras narrativas dos acontecimentos do dia primeiro de dezembro de 1640. Nessas narrativas o objetivo que se perseguia era assegurar que não houvesse alterações, pois o caos social, por regra geral atribuído ao terceiro estado, o denominado povo, vulgo ou plebe, era uma situação que se devia evitar de todas as maneiras. Quando se desatava, podia chegar a ser incontrolável, pondo em perigo as próprias bases da sociedade desse Ancien Régime. Os publicistas cuidaram de narrar os fatos do primeiro de dezembro de 1640 como um acontecimento espontâneo e pacífico, quase miraculoso. A intenção, obviamente, era evitar qualquer comparação com uma rebelião portadora de caos e inimiga da paz, do bem comum, ou contrária a um governo harmonioso, objetivos que perseguia a literatura jurídico-política da época. Entre esses autores, contam-se os seguintes: Antônio Pais Viegas, Manifesto do Reino de Portugal (1641); Luís Marinho de Azevedo, El Príncipe Encubierto ... (1642); e João de Vasconcelos, Restauração de Portugal prodigiosa (1643). Segundo a Relação de Nicolau da Maia de Azevedo, a intervenção dos altos membros do clero foi requerida para legitimar $\mathrm{o}$ ato político e, também, para acalmar possíveis altercados populares. $O$ narrador da Relação sabe ou intui que um milagre não pode ser apresentado sem uma certa dose de emoção. Os fatos desse primeiro de dezembro de 1640 são, a priori, os mesmos em todas estas narrativas, mas a representação varia (histoire e discours).

${ }^{31} \mathrm{O}$ braço do Cristo crucificado de 1640 facilitava uma relação paralelística com a lenda de Ourique, na origem do Reino, a qual desde 1597 tinha sido recuperada discursivamente. Ver: Marques, João Francisco (1989). Op. cit., vol., páginas. 228-241 e Marques, João Francisco (2010), Op. cit., páginas 158-159.
} 
A apropriação da pietas mariana para a causa bragantina também provém da primeira hora da Restauração. O oitavo Duque de Bragança chegou a Lisboa na manhã da quinta-feira do dia seis de dezembro de 1640. Dois dias depois, celebrou-se na capela real um ato litúrgico, no qual o franciscano Frei João de São Bernardino proferiu um sermão em que, por um lado, olhando para o passado, lembrava e exaltava a ancestral devoção mariana da Casa de Bragança e, por outro, olhando para o futuro que começava nesse imediato presente, encomendou Portugal e o futuro rei a Nossa Senhora. Concluiu o seu discurso com estas palavras: "Seja assim, Senhora, seja assim e eu vos prometo em nome de todo este reino, que ele agradecido levante um troféu a vossa Imaculada Conceição, que vencendo os séculos seja eterno monumento da Restauração de Portugal. ${ }^{32}$ Freire Costa e Soares da Cunha realçam com perspicácia que D. João IV percebeu que a capela real podia ser "não só o coração da Casa Real", como o centro "da própria governação". 33 Um lúcido ato de governo, próprio de uma época histórica confessional, que necessitava do apoio eclesiástico para um programa político de lealdade à nova dinastia, e de disciplina social.

Com o apoio das ordens eclesiásticas, e de forma especial dos jesuítas, D. João IV ativou o culto mariano, historicamente já vinculado à origem de Portugal: batalha do campo de Ourique C $^{34}$ (1139), batalha de Aljubarrota (1385), etc. Nas Cortes de Lisboa de 1645-1646 o rei declarou, a par com os três estados, que assumia a Imaculada Nossa Senhora da Conceição como padroeira de Portugal. Além do mais, os procuradores dos povos reunidos em Lisboa passaram a contribuir com 50 cruzados de ouro, como sinal de vassalagem, para o templo da Nossa Senhora da Conceição de Vila Viçosa (ducado de Bragança), que se considerava a primeira casa desta devoção na Península lbérica. Já as primeiras linhas da provisão de 25 de março de 1646 consolidam a devoção mariana e enraízam a sua origem na própria fundação de Portugal - Terra de Santa Maria -, da qual D. João IV se apresenta como o justo e agradecido herdeiro. Em decorrência desse

\footnotetext{
${ }^{32}$ Citado de Costa, Leonor Freire / Cunha, Mafalda Soares da (2008). D. João IV, Lisboa: Círculo de Leitores, Centro de Estudos dos Povos e Culturas de Expressão Portuguesa e Temas e Debates, p. 117118.

${ }^{33}$ Ibidem, p. 118.

${ }^{34}$ A primeira associação religiosa a essa batalha costuma lembrar a aparição de Cristo e traz à memória a frase "volo in te et in semine tuo, imperium mihi stabilire", palavras muito conhecidas e que o próprio Padre Vieira cita nas últimas linhas do Sermão dos Bons Anos; ver: Vieira, Antônio (2003). Op. Cit., p. 383. Por outro lado, muito citado é o quadro Conquista de Lisboa aos Mouros (c. 1650), de José de Avelar Rebelo, onde os mouros são representados como castelhanos. Nesse quadro também chama a atenção a presença, na parte superior esquerda, da Virgem Maria, com o filho no colo. Cristo, nesta representação pictórica de meados do século XVII, não se faz presente.
} 
juramento e do preito de vassalagem, os reis de Portugal nunca mais passaram a pôr a coroa na cabeça, como a iconografia posterior permite comprovar. ${ }^{35}$

A lembrança desse duplo agradecimento, intercessão da Virgem Maria na remota fundação do Reino e na sua recente e feliz Restauração, passa, pois, a ter uma visibilidade que se poderia atualizar, de acordo com as necessidades políticas, em cada ato público real, nas diversas artes iconográficas, nos púlpitos e na muito divulgada parenética impressa. Interessa lembrar que um juramento fundamental dessa provisão nos remete à concepção da Virgem Maria sem pecado original: "prometemos e juramos, com o Príncipe e Estados, de confessar e defender sempre, até dar a vida, sendo necessário, que a Virgem Senhora Mãe de Deus foi concebida sem pecado original". ${ }^{36} \mathrm{O}$ culto da Imaculada Conceição era bem mais recente do que a antiga devoção mariana, mas encontrava-se no seu pleno auge teológico. Nesses tempos históricos confessionais, ordens religiosas, universidades e outras instituições faziam com frequência demonstrações de adesão ao culto. Essa opção teológica tinha já uma mais que importante presença na Península Ibérica - também a Casa de Áustria a cultuava, e muito ativamente. Sendo assim, cada ato de afirmação sobre a pureza da Virgem Maria passava a ser uma forma de atualizar, indiretamente, a sua intercessão pela Restauração portuguesa. Era uma forma de apropriação política e portuguesa de uma importante tradição medieval - pietas mariana - com uma forte e contemporânea presença na Península Ibérica - culto da Imaculada Conceição.

Interessa observar que a dinastia da Casa de Áustria tinha como costume ancestral reverenciar a eucaristia, devoção que recebia o nome de pietas austriaca. A sua origem parte de uma lenda medieval associada ao imperador Rodolfo I (1218-1291), origem da dinastia. A lenda refere o encontro de Rodolfo I com um sacerdote que levava a pé a hóstia consagrada, o viático, a um moribundo. No momento e lugar do encontro, o sacerdote via-se impossibilitado de continuar o seu caminho por culpa de um rio, cuja corrente, demasiado forte, não Ihe permitia passar. Na seguinte sequência da lenda,

\footnotetext{
${ }^{35}$ Muito extensa é a bibliografia sobre a devoção e a piedade mariana em Portugal. Interessa-me, aqui, somente chamar a atenção para a sua utilização narrativa no marco da Restauração. Para mais informações, remeto a algumas fontes mais autorizadas: Marques, João Francisco (2000). "Oração e devoções". In Marques, João Francisco / Gouveia, João Camões, História Religiosa de Portugal. Volume 2. Humanismos e Reformas, Lisboa: Círculo de Leitores, p. 603-670, especialmente 625-634. Para as fontes primárias, são muito úteis os seguintes livros: Marques, José (1987). Bibliografia mariana portuguesa do século XVI, Braga: separata da revista Theologica, vol XX, fasc. I-IV de 1985; e Pericão, Maria da Graça (1990-91). Bibliografia mariana portuguesa dos séculos XVII e XVIII, Lisboa: Didaskalia. Revista da Faculdade de Teologia de Lisboa. Universidade Católica Portuguesa.

${ }^{36}$ Fonseca, Francisco Belard da (1955), A Ordem Militar de Nossa Senhora da Conceição de Vila Viçosa. Lisboa: Fundação da Casa de Bragança. p. 275.
} 
Rodolfo I Ihe teria emprestado o seu cavalo para superar o obstáculo e, já na outra margem, teria renunciado a montá-lo novamente, pois o animal acabava de ter o privilégio de transportar o Corpo do Senhor, logo não poderia ser utilizado para outros fins. ${ }^{37}$ Em agradecimento por esse gesto, o sacerdote teria profetizado um esplendoroso e inigualável futuro para ele e para os seus descendentes, para a Casa de Áustria. Em termos narrativos, observa-se que o herói se encontra longe de casa, no campo, em movimento, e supera uma inesperada prova - ajudar o sacerdote a levar o viático -, o que Ihe garante um prêmio: um objeto, um auxílio mágico, uma profecia (que se cumprirá).

Desde então, os membros ou altos representantes da Casa de Áustria, tanto na Europa central como na Península Ibérica e inclusive na América, adquiriram o costume de repetir o gesto, de atualizá-lo: quer dizer, acompanhar um sacerdote que leva a hóstia consagrada; por vezes, inclusive, cedendo piedosamente o seu meio de transporte. E depois esses atos passavam a ter uma representação narrativa e inclusive visual: sermões e outros textos religiosos, antologias das academias poéticas, peças dramáticas, obras historiográficas, ensaios políticos, quadros ou pinturas murais afresco, etc. Autores como Calderón de la Barca, Bances Candamo, Solórzano Pereira, Rubens, Nieremberg, Lipsius, entre outros muitos, contribuíram à reiteração e à divulgação da pietas austriaca.

A associação com a Casa de Áustria chegou a ser um tópico indiscutível. Por exemplo, no livro La Fama Austriaca o Historia Panegírica de la vida y hechos del Emperador Fernando Segundo (1641), José Pellicer de Ossau y Tovar enumera as virtudes do imperador e destaca a sua permanente veneração pela hóstia consagrada, fato que associa à própria dinastia: "La frecuencia de los santos Sacramentos, $y$ veneración del santísimo de la Eucharistia, continua y admirable, o para decirlo mejor, Austriaca."38 Essa estreita relação entre os Áustrias e a devoção eucarística, especialmente segundo o modelo narrativo da lenda iniciada com Rodolfo I, também era conhecida em Portugal. Antônio Carvalho de Parada escreveu na sua Arte de reinar

\footnotetext{
${ }^{37}$ Como se sabe, desde Santo Tomás de Aquino o pão e o vinho transubstanciam-se verdadeiramente no corpo e sangue de Cristo (Summa Theologica, Tertia partis, Quæstio LXXIII, I). O Concílio de Trento confirmou essa transubstanciação, fundamental para a Contrarreforma. Uma segunda lenda colegitimava religiosamente o poder de Rodolfo I: a assunção da cruz como cetro do Rei de Romanos (fiducia in crucem Christi). Sobre a devoção religiosa da Casa de Áustria, ver: Coreth, Anna (1982). Pietas Austriaca. Österreichische Frömmigkeit im Barock. Viena: Verlag für Geschichte und Politik. Mais especificamente sobre a lenda aqui resumida, ver: Rodrigues-Moura, Enrique (2006). "Religión y poder en la España de la Contrarreforma. Estructura y función de la leyenda de los Austria devotos de la Eucaristía". In Maldonado Alemán, Manuel (editor), Austria, España y Europa: identidades y diversidades, Sevilla: Universidad de Sevilla, 11-30.

${ }^{38}$ Pellicer de Ossau y Tovar, José (1641). La Fama Austriaca o Historia Penegírica de la ejemplar vida y hechos gloriosos del Emperador Fernando Segundo..., Barcelona, Sebastián y Jaime Matevad, p. 155 frente.
} 
(1643) que os Áustrias eram poderosos "por causa de uma cortesia feita a um sacerdote indo administrar o Santíssimo Sacramento a um enfermo" e, continua Parada, a decadência que estavam vivendo no momento presente nascia por não se lembrarem da origem do seu poder: "quando estas razões esque[ce]m por antigas, ou por serem favores, que sempre estes trazem consigo o esquecimento, lancem os olhos ao açoite, que em seus Reinos vêm" ${ }^{39}$

A apropriação da pietas mariana para a causa da Restauração deve ser interpretada, como aqui se sugere, como uma forma mais de legitimar uma mudança dinástica perante uma ainda muito poderosa monarquia hispânica. Nesse caso, a diferença da pietas austriaca, ou inclusive do braço do Cristo crucificado, não há uma historie completa. A narração reduz-se ao mínimo, ao agradecimento final, quando o rei e os três estados juram defender a Imaculada Conceição da Nossa Senhora e, principalmente, quando o monarca entrega a sua coroa em sinal de agradecimento. Mesmo sendo só uma minissequência narrativa, o receptor conhece o marco narrativo geral, no sentido da "schematic narrative templates" proposta por Wretsch, e preenche os espaços vazios, que não foram contados ou apresentados nesse momento. Explica Antônio Carvalho de Parada que Deus "Ihes mandava que quando se coroassem [os Príncipes] Ihes pusessem juntamente com a Coroa a lei para que entendessem que 0 poder que Ihe dava com a coroa era dependente da lei de Deus". 40 Simbolicamente, quando o rei entrega a coroa a Nossa Senhora, estamos perante uma forma de mostrar a sua vassalagem a Deus, mantendo a lei divina como base estrutural da república, à qual ele próprio tem que se submeter. ${ }^{41} \mathrm{~A}$ mensagem política é clara, e a intercessão da Virgem Maria serve para enfatizar uma história acontecida, agora não narrada, mas que o receptor conhecia - a Restauração, com a estrutura antes apresentada -, e era capaz de decodificá-la e interpretá-la a posteriori, partindo somente desse agradecimento.

Antes de terminar, é necessário comentar sucintamente alguns fatos históricos relativos à devoção do Santíssimo Sacramento em Portugal, com a finalidade de evitar uma simplificada visão dual que possa atribuir uma pietas mariana unicamente bragantina e uma pietas austriaca exclusiva da Casa de Áustria. A devoção pela eucaristia possuía

\footnotetext{
${ }^{39}$ Parada, Antônio Carvalho de (1643). Op. Cit., f. 53 frente.

${ }^{40}$ Parada, Antônio Carvalho de (1643). Op. Cit., f. 47 frente.

${ }^{41}$ Ponha-se em comparação essa submissão com a que explica Antônio Carvalho de Parada: "Estima Deus os Príncipes pios e afeiçoados ao culto divino e à religião: porque quando esta seja errada ainda ficam de ganho, não em bens espirituais, pois estes se fizeram para os que servem ao Deus verdadeiro, mas nas virtudes morais que se lhe pagam em felicidades temporais e em utilidade do povo: porque monta muito em respeito do governo reconhecer o Príncipe superioridade a outra lei e entender que a obediência, que seus vassalos Ihe têm, deve ele ter a outro Príncipe mais soberano". Parada, Antônio Carvalho de (1643). Op. Cit., f. 47 verso.
} 
uma grande irradiação em Portugal e D. João IV mostrou publicamente que observava essa tradição com fervor. Os panegiristas da época deixaram sobradas amostras desse sentimento religioso exteriorizado. Nesse sentido, a libertação de Portugal seria devido à devoção eucarística do Reino e do monarca.

Mesmo assim, a reverência pela eucaristia não alcançou a categoria de devoção exclusiva dos Bragança, como a particular narração sobre a "cortesia feita a um sacerdote" por Rodolfo I passou a ser uma pietas austriaca. ${ }^{42}$ A devoção eucarística tinha um importante fundo confessional europeu, pois diferenciava os campos políticos da Reforma, que não a cultuavam, dos da Contrarreforma, que a veneravam publicamente, e de modo especial nas procissões anuais do Corpus Christi. ${ }^{43}$ Uma mesma função política pode ser apreciada na devoção à Imaculada Conceição, que tinha grande predicamento na Península Ibérica. ${ }^{44}$ Esse culto ganhou ainda maior força por petição de Filipe III de Espanha ao Papa para que declarasse o dogma da Imaculada Conceição de Maria. A maioria das ordens religiosas, muitas Universidades, entre elas Coimbra (1617) e Salamanca (1618), e não poucos senados das cidades, entre eles o de Lisboa (1618), aderiram com entusiasmo ao projeto. Mesmo assim, a apropriação desse culto mariano pelos Bragança implicava, creio eu, algumas interessantes particularidades, pois estabelecia uma continuidade histórica entre D. Afonso Henriques, na origem do Reino, e a recente Restauração, sendo D. João IV a conexão necessária entre esses distantes tempos. A isso tem que se somar o efeito visual de D. João IV agradecer a intercessão de Nossa Senhora com a entrega da coroa real. A mariologia ibérica da época associou a Virgem Maria a Cristo na obra da salvação humana; e em Portugal era lembrada também

\footnotetext{
42 Interessa aqui assinalar que acompanhar o viático era uma tradição que também se realizava em Portugal e nas conquistas. Por exemplo, na noite de 30 para 31 de agosto de 1666, em Pernambuco, os conjurados que depuseram pela força o governador Jerônimo de Mendonça Furtado "concertaram o plano de simular um enfermo [...] com aperto de necessitar o sacramento do Viático Eucarístico, que era de praxe o governador acompanhar, segundo o costume dos portugueses da mais alta qualidade". O plano deu resultado e lograram prender sem grande resistência o governador. Ver: Garcia, Rodolfo (1973). "Deposição de Jerônimo de Mendonça Furtado, Governador de Pernambuco - Ano de 1666". In Garcia, Rodolfo, Escritos avulsos, Rio de Janeiro: Biblioteca Nacional, p. 59.

${ }^{43}$ Nesse sentido, segundo Francisco Brandão, foi o fato de D. João IV estar acompanhando a "procissão Geral do Corpo de Deus", em 1647, o que Ihe salvou a vida, quando já estava na mira do português Domingos Leite Pereira. Nesse mesmo texto de 1647, Brandão também reconhece que "os Príncipes Austríacos se atribuem" uma especial "reverência e veneração" pela Eucaristia. Brandão, Francisco (1647). Relação do Assassínio intentado por Castela contra a Majestade del-Rei D. João IV, Nosso Senhor e impedido miraculosamente, Lisboa: Paulo Craesbeeck, sem foliação, f. 2 verso.

44 E também em outros espaços político-culturais continentais, como testemunham as inúmeras Mariensäulen (estátuas da Mãe de Deus que se assentam sobre uma coluna) que se construíram na Europa Central a partir do modelo da levantada em München (1638). Para o período que vai de 1650 a 1780 e tendo em conta só os territórios de Boêmia e Morávia, há catalogadas mais de 162 Mariensäulen. Ver: Tipton, Susan (1995). "«Super aspidem et basiliscum ambulabis ...» Zur Entstehung der Mariensäulen im 17. Jahrhundert". In Breuer, Dieter (editor), Religion und Religiosität im Zeitalter des Barock, Wiesbaden: Harrassowitz, p 375-397.
} 
pela sua intercessão por uma pacífica Restauração. Importa salientar, tendo em conta esses dados devocionais, a multiplicação de fenômenos religiosos e a sua variada e em absoluto unívoca significação, dependente esta em grande parte do respectivo ato performativo.

A lenda do braço de Cristo é uma narrativa com uma base referencial, pois os publicistas da Restauração enumeram as testemunhas do acontecimento. Por sua vez, o agradecimento feito a Nossa Senhora tem mais o caráter de uma narrativa dialógica - em diálogo com outras narrações -, pois não há forma de provar empiricamente essa intercessão da Virgem Maria, a não ser pelo êxito da Restauração - que não estava assegurado por volta do dia 8 de dezembro de 1640 - ou por meio da fé. Apesar dessa interessante diferença, nenhuma das duas narrativas depende da ditadura do referencial, dos fatos empíricos, pois a primeira era um milagre e a segunda um sinal de agradecimento por algo já feito, e também miraculoso. O espaço da fé não permite comprovações empíricas, que, diga-se de passagem, ninguém na época exigia.

Ao mesmo tempo, ambas as narrações baseiam o seu poder de convicção na existência de uma base cultural confessional católica muito divulgada por meio de um ativo disciplinamento eclesiástico-social que legitimava a organização política do corpo místico da república. Essas duas narrações serviam como exemplos retóricos que, uma vez relatados no púlpito, ou em outros lugares e por outros meios, obrigava ao auditório a intuir o argumento subjacente - exemplum e argumentum, segundo Quintiliano -, a narração que o justificava. Essa narração subjacente resumia-se em uma Restauração prodigiosa, triunfante e feliz. 


\section{Referências Bibliográficas}

Álvarez-Ossorio Alvariño, Antonio (2002). "La sacralización de la dinastía en el púlpito de la Capilla Real en tiempos de Carlos II”. In Criticón, n. 84-85, p. 313-332.

[Azevedo, Nicolau da Maia de] (2007). Relação de tudo o que passou na Felice aclamação do mui alto e mui poderoso rei dom João o IV nosso senhor, cuja Monarquia prospere Deus por largos anos, Coimbra: Faculdade de Letras da Universidade de Coimbra. [Texto anônimo e sem data; nome do autor segundo a bibliografia, como a data: 1641]

Bouza Álvarez, Fernando Jesús (1986). "«Clarins de Jericho». Oratoria sagrada y publicística en la Restauração portuguesa". In Cuadernos de Historia Moderna y Contemporánea, vol. 7, p. 13-31.

Bouza [Álvarez], Fernando Jesús (1991). "Primero de diciembre de 1640.: ¿una revolución desprevenida?". In Manuscrits, n. 9, p. 205-225.

Bracamonte, Domingos Pereira (1642). Banquete que Apolo hizo a los embajadores del Rey de Portugal Don Juan Cuarto. En cuyos platos hallarán los señores convidados, mezclada con lo dulce de alguna poesía y política, la conservación de la salud humana, Lisboa: Lourenço de Amberes.

Brandao, Francisco (1642). Discurso gratulatório sobre o dia da Felice Restituição e Aclamação da Majestade Del-Rei D. Joao IV N.S., Lisboa: Lourenço de Anveres.

Brandão, Francisco (1647). Relação do Assassínio intentado por Castela contra a Majestade del-Rei D. João IV, Nosso Senhor e impedido miraculosamente, Lisboa: Paulo Craesbeeck.

Calafate, Pedro (2001). “A reflexão portuguesa sobre a política nos séculos XVI e XVII”. In Calafate, Pedro (direção), História do Pensamento Filosófico Português. Volume II. Renascimento e Contra-Reforma, Lisboa: Caminho, p. 663-700. 
Cardim, Pedro (1999). "Amor e amizade na cultura política dos séculos XVI e XVII". In Lusitânia Sacra, segunda série, n. 11, p. 21-57.

Cardim, Pedro (2001). "Religião e ordem social. Em torno dos fundamentos católicos do sistema político do Antigo Regime". In Revista de História das Ideias, vol. 22, p. 133-174.

Carey, Benedict (2009). "Discurso, e não trejeito, pode revelar a verdade". In The New York Times versão para a Folha de São Paulo, 25 de maio, p. 5.

Coreth, Anna (1982). Pietas Austriaca. Österreichische Frömmigkeit im Barock. Viena: Verlag für Geschichte und Politik. [Trata-se da segunda edição ampliada. A primeira é de 1954]

Costa, Leonor Freire / Cunha, Mafalda Soares da (2008). D. João IV, Lisboa: Círculo de Leitores, Centro de Estudos dos Povos e Culturas de Expressão Portuguesa e Temas e Debates.

Elliot, John H. (1992). "A Europe of Composite Monarchies". In Past \& Present, n. 137, novembro, p. 48-71.

Fonseca, Francisco Belard da (1955), A Ordem Militar de Nossa Senhora da Conceição de Vila Viçosa. Lisboa: Fundação da Casa de Bragança.

Garcia, Rodolfo (1973). "Deposição de Jerônimo de Mendonça Furtado, Governador de Pernambuco - Ano de 1666". In Garcia, Rodolfo, Escritos avulsos, Rio de Janeiro: Biblioteca Nacional, p. 51-62. [Texto de 1939]

Hespana, António M. (1994). As Vésperas do Leviathan. Instituições e poder político. Portugal, século XVII, Coimbra: Almedina.

Kindt, Tom / Müller, Hans-Harald (editores) (2003). What Is Narratology? Questions and Answers regarding the Status of a Theory, Berlin / New York: Walter de Gruyter. 
Marques, José (1987). Bibliografia mariana portuguesa do século XVI, Braga: separata da revista Theologica, vol XX, fasc. I-IV de 1985.

Marques, João Francisco (1989). A parenética portuguesa e a Restauração, 1640-1668. A Revolta e a Mentalidade, 2 vols., Porto: Instituto Nacional de Investigação Científica.

Marques, Joao Francisco (2000). "Oracao e devoções”. In Marques, João Francisco / Gouveia, João Camões, História Religiosa de Portugal. Volume 2. Humanismos e Reformas, Lisboa: Círculo de Leitores, p. 603-670.

Marques, João Francisco (2010). A parenética portuguesa e a dominação filipina, Lisboa: Imprensa Nacional-Casa da Moeda. [Primeira edição de 1986]

Meneses, João Afonso de (1582). Carta geral edital. 20 de dezembro. [Sem lugar de impressão. Documento de três páginas não numerado. Encontra-se digitalizado pela Biblioteca Nacional de Lisboa: http://purl.pt/14941 (acessado por última vez em 15 de março de 2010)].

Melo, Francisco Manuel de (1995). Tácito Português. Vida, Morte, Ditos e Feitos de El Rey Dom João IV de Portugal, Lisboa: Sá da Costa. [Livro inconcluso que se conservou inédito até o século $\mathrm{XX}]$

Negredo del Cerro, Fernando (2002). "La palabra de Dios al servicio del Rey. La legitimación de la Casa de Austria en los sermones del siglo XVII”. In Criticón, n. 84-85, p. 295-311.

Oestreich, Gerhard (1969). "Strukturprobleme des europäischen Absolutismus". In Oestreich, Gerhard, Geist und Gestalt des frühmodernen Staates. Ausgewählte Aufsätze, Berlin: Duncker \& Humblot, p. 179-197.

Paiva, José Pedro (2000). "A Igreja e o Poder". In Marques, João Francisco / Gouveia, João Camões, História Religiosa de Portugal. Volume 2. Humanismos e Reformas, Lisboa: Círculo de Leitores, p. 135-185. 
Paiva, José Pedro (2007). "El Estado en la Iglesia y la Iglesia en el Estado. Contaminaciones, dependencias y disidencia entre la monarquía y la Iglesia del reino de Portugal (1695-1640)". In Manuscrits, n. 25, p. 45-57.

Parada, Antônio Carvalho de (1628). Discurso político. Fundado en la Doctrina de Cristo nuestro Señor, y de la Sagrada Escritura. Si conviene al gobierno espiritual de las almas, o al temporal de la República, aprobarse el modo de predicar de reprehender a los Príncipes y Ministros, Lisboa: Pedro Craesbeeck.

Parada, Antônio Carvalho de (1643). Arte de reinar. Ao potentíssimo Rei D. João IV nosso Senhor Restaurador da liberdade portuguesa. Bucelas: Paulo Crasbeck. [O catálogo da Biblioteca Nacional de Lisboa considera que este livro é do ano 1644, mas, como se pode comprovar na folha das licenças, está taxado no dia 5 de dezembro de 1643, data em que o livro, sem nenhuma dúvida, já estava impresso]

Pellicer de Ossau y Tovar, José (1641). La Fama Austriaca o Historia Panegírica de la ejemplar vida y hechos gloriosos del Emperador Fernando Segundo..., Barcelona, Sebastián y Jaime Matevad.

Pericão, Maria da Graça (1990-91). Bibliografia mariana portuguesa dos séculos XVII e XVIII, Lisboa: Didaskalia. Revista da Faculdade de Teologia de Lisboa. Universidade Católica Portuguesa.

Reinhard, Wolfgang (1981). "Konfession und Konfessionalisierung in Europa". In Reinhard, Wolfgang (editor), Bekenntnis und Geschichte. Die Confessio Augustana im historischen Zusammenhang, München: Vögel, p. 165-189.

Reinhard, Wolfgang (1994). "Disciplinamento sociale, confessionalizzazione, modernizzazione. Un discorso storiografico". In Prodi, Paolo / Penuti, Carla (editores), Disciplina dell'anima, disciplina del corpo e disciplina della società tra medioevo ed età moderna, Bologna: II Mulino, p. 101-123.

Rodrigues-Moura, Enrique (2006). "Religión y poder en la España de la Contrarreforma. Estructura y función de la leyenda de los Austria devotos de la Eucaristía". In Maldonado 
Alemán, Manuel (editor), Austria, España y Europa: identidades y diversidades, Sevilla: Universidad de Sevilla, 11-30.

Rodrigues-Moura, Enrique. (2007). "Abraham a Sancta Clara, Paravicino y Vieira. Apud Europaeos et Occidentales populos". In Danler, Paul et alii (editores.), Österreich, Spanien und die europäische Einheit / Austria, España y la unidad europea. XI. SpanischÖsterreichisches Symposium. Innsbruck: Innsbruck University Press, 3-34.

Schilling, Heinz (1981). Konfessionskonflikt und Staatsbildung. eine Fallstudie über das Verhältnis von religiösem und sozialem Wandel in der Frühneuzeit am Beispiel der Grafschaft Lippe, Gütersloh: Mohn.

Solórzano y Pereira, Juan de (1972). Política indiana, tomo III, Madrid: Biblioteca de Autores Españoles, vol. CCLIV. [A primeira edição castelhana, publicada em Madrid em seis livros, é de 1647]

Stolleis, Michael (1995). "Religion und Politik im Zeitalter des Barock. 'Konfessionalisierung' oder 'Säkularisierung' bei der Entstehung des frühmodernen Staates?". In Breuer, Dieter (editor), Religion und Religiosität im Zeitalter des Barock, Wiesbaden: Harrassowitz, p. 23-42.

Tipton, Susan (1995). “«Super aspidem et basiliscum ambulabis ...» Zur Entstehung der Mariensäulen im 17. Jahrhundert”. In Breuer, Dieter (editor), Religion und Religiosität im Zeitalter des Barock, Wiesbaden: Harrassowitz, p 375-397.

Torgal, Luís Reis (1981-1982). Ideologia política e Teoria do Estado na Restauração, dois volumes, Coimbra: Biblioteca Geral da Universidade.

[Viegas, Antônio Pais] (1641). Manifesto do Reino de Portugal. No qual se declara o direito, as causas e o modo que teve para eximir-se da obediência Del Rey de Castela e tomar a voz do Sereníssimo Dom João IV do nome e XVIII entre os Reis verdadeiros deste Reino, Lisboa: Paulo Craesbeeck. [Documento anônimo; nome do autor segundo a bibliografia] 
Vieira, Antônio (2003). "Semão dos Bons Anos". In Vieira, Antônio, Sermões, tomo 2, São Paulo: Hedra, p. 363-384. [Sermão impresso em 1642]

Wertsch, James V. (2002). Voices of Collective Remembering, Cambridge: Cambridge University Press.

White, Hayden (1978). "The historical text as literary artifact". In White, Hayden, Tropics of Discourse. Essays in cultural criticism, Baltimore / London: The Johns Hopkins University Press, p. 81-100.

Xavier, Ângela Barreto (1998). "El Rei aonde póde, \& não aonde quer". In Razões da Política no Portugal Seiscentista, Lisboa: Colibri. 